\title{
GIDA ETİKETLERİNDE YER ALAN BİLGİLERİN SAĞLIKLI ALGILANMA (HEALTH HALO) ETKİSI
}

\author{
Atilla Bektaş ${ }^{* 1}$, Meltem Ulusoy ${ }^{2}$, Vuslat Bektaş ${ }^{3}$ \\ 1) Özel Ankara Cerrahi Tip Merkezi, Gastroenteroloji Bölümü, Ankara, Türkiye \\ 2) Hacettepe Üniversitesi Biyoloji Bölümü, Uygulamalı Biyoloji ABD, Ankara, Türkiye \\ 3) Tarım ve Orman Bakanlığı, SGB Emekli, Ankara, Türkiye
}

Geliş / Received: 27.03.2020; Kabul / Accepted: 06.06.2020; Online bask1 / Published online: 16.06.2020

Bektaş, A., Ulusoy, M., Bektaş, V. (2020). Gıda etiketlerinde yer alan bilgilerin sağlıklı algılanma (health halo) etkisi. GIDA (2020) 45(3) 590-599 doi: 10.15237/gida.GD20045

Bektaş, A., Ulusoy, M., Bektaş, V. (2020). Health halo effect of food labels. GIDA (2020) 45(3) 590-599 doi: $10.15237 /$ gida.GD20045

\section{ÖZ}

Sosyal psikolojide ilk etki olarak bilinen halo etkisi/ hatası bir nesne veya kişi ilk görüldüğünde edinilen anlık izlenim olup, kararların temelini oluşturur. Günümüzde birçok gıda şirketi, ürün etiketlerinde yer alan FOP (front on package) bilgisini kullanarak bir çeşit sağlıklı algılanma etkisi yaratmayı satış stratejisi olarak kullanmaktadır. Örneğin gıda etiketleri üzerinde yer alan, düşük yağlı, tuzsuz, düşük kalorili, glutensiz, yüksek proteinli, yüksek lifli, GDO’suz, gibi gıdanın içerik bilgilerinin yanında; ürünün üretim sürecindeki tercihleri ifade eden organik, doğal, katkısız, "süper gıda" ya da "fair trade" gibi etik ifadeler kullanılmaktadır. Sağlıklı algılanma etkisi ile tüketici tercihleri manipüle edilmektedir. Çölyak hastalğı, fenilketonürü hastalığı gibi özel hastalıklar için hazırlanan ürünler ve laktozsuz, tuzsuz vb durumlar hariç; sağlıklı algılanma etkisi yaratan zihinsel kısa yolları devre dışı bırakmak için "düz paketleme" önerilmektedir.

Anahtar kelimeler: Sağlıklı algılanma etkisi, ilk etki, gıda etiket bilgileri

\section{HEALTH HALO EFFECT OF FOOD LABELS}

\begin{abstract}
Nowadays, many food companies are creating some kind of health halo effect with the FOP (front on package) information on their product packaging. The halo effect/mistake, known as the first effect in social psychology, is the instant impression you get when you first see an object or person, and it is the basis of how we evaluate and assess that person or object. For example, in addition to ingredients information that appears on the FOP such as low-fat, no-salt, low-calorie, gluten-free, high-protein, high-fiber, GMO-free information is also provided about the production process used to produce the product, such as organic, natural, unadulterated, "super food", "fair trade". Unfortunately, consumer preferences are being manipulated through health halo effect. With the exception of foods that are sold for special diseases such as celiac, or phenylketonuria diseases, or for lactose-free, salt-free, etc products "plain packaging" would be recommended to disable mental short cuts that create health halo effect.
\end{abstract}

Key words: Health halo effect, halo effect, food label information

* Yazışmalardan sorumlu yazar / Corresponding author

$\triangle$ atillabektas2000@yahoo.com
Atilla Bektaş; ORCID no: 0000-0001-7775-3770

留: (+90) 3124738855 司: (+90) 3124737222

Meltem Ulusoy; ORCID no: 0000-0002-3885-2714

Vuslat Bektaş; ORCID no: 0000-0002-7885-2997 


\section{GİRİ̧̧}

G1da etiketleri üzerinde düşük yağlı, tuzsuz, düşük kalorili, glutensiz, yüksek proteinli, yüksek lifli, GDO'suz, gibi gıdanın içerik bilgilerinin yanında; ürünün üretim sürecindeki tercihleri ifade eden organik, doğal, katkısız, süper gıda tanımları, fair trade gibi adil ticaret yapıldığına ilişkin ifadeler kullanılmaktadır. Her iki bilgilendirme de tüketicide sağlıklı alg1lanma etkisi yaratmakta ve tüketicinin $\mathrm{o}$ ürüne yönelmesine neden olmaktadır.

Etiket bilgisinin (görsel ya da yazllı ifade) tüketicide yarattı̆g bu alg1, ilk etki (halo effect) olarak üründen bağımsız olarak gelişmekte ve ürünün gerçekte olduğundan farklı değerlendirilmesine yol açabilmektedir (Talati, et.al., 2016; Fernan, et.al., 2018)

Farklı markalar satış amaçlı olarak, etiket bilgileri üzerinden tüketici eğilimlerini manipüle etmektedirler. Bu şekilde ürünün daha sağlıklı algılanmasını, tüketicinin seçimini ve tüketim miktarını etkilemektedirler. Bu konudaki mevzuat yetersizliği ve uygulamadaki aksaklıklar nedeniyle tüketicinin yanılması söz konusudur

\section{BESLENME VE HASTALIK İLİŞKİSİ}

Geçmişte ölümlere neden olan mikrobik hastalıkların yerini günümüzde kalp damar hastalıkları, obezite, tip 2 diyabet, nörodejeneratif hastalıklar (Alzheimer hastalı̆̆1, Parkinson hastalığ vb) gibi kronik hastalıklar ve kanser almıştır (Mozaffarian, 2016).

FDA raporuna göre, Dünya'daki 10 ölüm nedeninden 6'sında gida, beslenme ve yaşam tarz1 etkili olmaktadır (FDA, 2018). Dolayısıyla "sağlıksız beslenme" ile kronik hastalık ve kanser oluşumu arasındaki pozitif ilişsi her geçen gün önem kazanmaktadır. Günümüzde sanayileşme ile insanlar "Akdeniz diyeti" gibi geleneksel beslenme şekillerini terk edip, "Batı tipi beslenme" "Western diet" olarak da adlandırlan sağlıksız bir beslenme şekline geçmektedirler. Şekerli/gazlı içecekler, fazla miktarda doymuş yağ içeren hayvansal gidalar, tatlılar, rafine unlu mamuller, tuzlu atştırmalıklar ve işlenmiş gidalar ile tekrar tekrar 1sitllip servis edilen yiyecekler bu diyetin temelini oluşturmaktadır. "Western diet"e geçiş obezite ve gidalara bağlı kronik hastalıklara ve bazı kanser türlerinde artışa neden olmaktadır (CastroQuezada, et.al., 2014; Mentella, et.al.,2019).

Beslenme (nutrisyon) biliminde, 1780’lerden sonra besinlerin kimyasal yapisinin aydınlatılmasıyla "kimyasal devrim" yaşandı. Bu şekilde "klasik beslenme anlayışı" oluştu ve beslenmede besin ögelerinin eksikliğinin, hastalık oluşumuna etkisi ortaya konuldu. Eskiden uzun deniz seferlerine çıkan denizcilerde, taze meyve sebze tüketmemeleri nedeniyle görülen skorbüt hastalı̆̆ının $\mathrm{C}$ vitamini eksikliğinden kaynaklandığı, beriberi hastalığının B1 vitamini eksiliğinde ortaya çıtı̆̆ örnek olarak verilebilir (Carpenter, 2003; Lee, 2019). Tipta bir ya da daha fazla besin öğesinin vücut dengesini bozacak şekilde yetersiz alınması sonucunda ortaya çıkan klinik tablo malnütrisyon olarak adlandırılmaktadır. Bu tablo genel olarak ilk beş yaşta protein ve enerji malnütrisyonu (PEM) olarak karşımıza çıkmaktadır (WHO, Geneva, 2010).

Klasik beslenme anlayışı ile "Yeterli ve dengeli beslenme" kavramı ortaya çımışır. Böylelikle insanın yaş, cinsiyet ve fizyolojik durumuna göre; gereksinimi olan bütün besin öğelerini yeterli miktarda ve dengeli olarak alması hedeflenmiştir. Son y1llarda makrobesin ve vitamin-mineral gibi mikrobesinlerin yanı sıra fitokimyasalların, proprebiyotikler, biyoaktif peptitler ve diyet lifi gibi fonksiyonel gidaların da beslenmedeki öneminin anlaşılmasıyla "Optimal beslenme" kavramı ortaya çıkmışur (Percival, 1997; Hasler, 1998; Shao,et.al., 2017).

1989 da başlayan ve 14 yll sonra 2003 yilında tamamlanan, İnsan Genom Projesi (HUGO) ile gerçekleşen 'genomik devrim', hastalıkların önlenmesi ve tedavisinde önemli bir devrin başlamasına neden olmuştur (Van Ommen, 2002; Phelan, et.al., 2013; Shamim,et.al.,2017). Genomik devrimle, besin ögelerinin doğrudan ve dolaylı olarak gen ekspresyonu üzerindeki etkileri incelenmeye başlanmıştur (Şekil 1). 


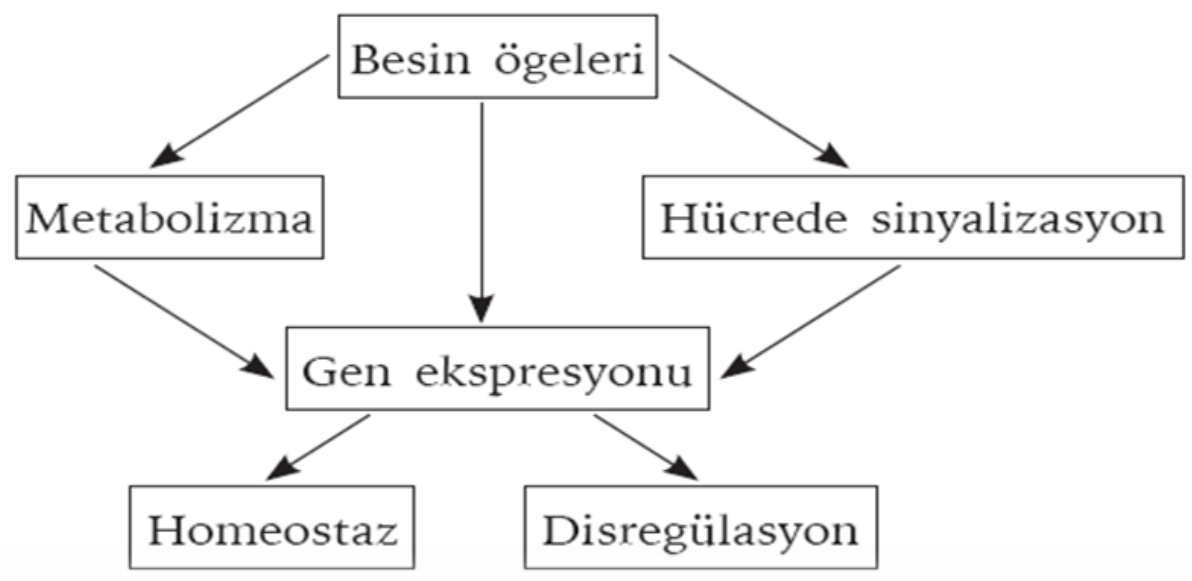

Şekil 1. Gen ekspresyonu

Bütün bunlar kronik hastalıkların ve kanserin önlenmesinde "akılc1 diyet (intelligent)" ya da "tailor made" beslenme kavramlarını tartışmaya açmışır. Böylece bireylerin genetik yapılarına dayalı farklılıklar nedeniyle, uygulanan diyete verdikleri farklı tepkiler, insan sağlığının iyileştirilmesi ve hastalıkların önlenmesinde kullanılabilir ( Trujillo, et.al., 2006; Guasch-Ferré, et.al.,2018).

Bugün coğrafi sınırların aşıldığı global dünyada, herhangi bir yerde üretilen, gidaya erişim kolaylaşmıştur. Tüketicinin, market ve pazar alışverişlerinde farklı yerlerde üretilmiş pek çok yeni ürünle karşılaşma olanağının artırması, bireylerin gida tercihlerinde, daha bilinçli, dikkatli ve seçici olmalarını gerektirmektedir.

\section{SAĞLIKLI ALGILANMA ( HALO ) ETKİSI NEDİR}

Sosyal psikolojide ilk etki olarak bilinen halo etkisi/ hatası (halo effect)bir nesne veya kişi ilk görüldüğünde edinilen anlık izlenim olup, alınan kararların temelini oluşturur. Gıda etiketlerinin halo etkisinde iki mekanizma rol oynamaktadir.

Self-Regulatory Mechanisms: Tüketici bir giday1 lezzeti için ya da faydası için tüketmektedir.

Inferential Mechanisms: Tüketici bir reklamda yer alan sağlıklı ifadesini kabul edilmiş, onaylanmış bir bilgi olarak görür ve sorgulamadan kabul eder (Chandon, et.al. 2007).

\section{GIDA ETIIKET BİLGILLERININ GIDA ETİĞİ VE SAĞLIKLI ALGILANMA ETKİİ (HEALTH HALO EFFECT) AÇISINDAN DEĞERLENDİRİLMESİ}

Günümüzde birçok gida şirketi ürün etiketlerinde yer alan FOP (front on package) bilgisiyle bir çeşit sağlıklı algilanma etkisi yaratmaktadır (Méjean, et.al.,2013).

G1da etiketinde yer alan düşük yağll, düşük kalorili, glutensiz, yüksek proteinli, yüksek lifli, GDO'suz, gibi gıdanın içerik bilgilerinin yanında; ürünün üretim sürecindeki tercihleri ifade eden organik, doğal, katkısız, adil ticaret (fair trade) vb ifadelerin de sağlıklı algılanma etkisi yarattı̆̆ konusunda pek çok akademik çalışma bulunmaktadır (Orquin, et.al., 2015; Talati, et.al., 2016; Ikonen, et.al., 2019).

Sektör kimi zaman gida etiketlerinde dini inançlara uygun olarak üretildiğini öne sürdüğü g1dalarla da health halo etkisi oluşturabilmektedir.

Örneğin etnik merkezli (ethnocentric) pazarlamada ön plana çıkan etiketlerdeki helal ürün ifadesi, gida pazarında en çok kullanılan dinsel içerik olmuştur. (Wilkins, et.al.,2019). 
Piyasada talep yaratmak, rekabet edebilmek için tüketici eğilim ve davranışları yönlendirilmektedir. Sağlık mı? Kâr mı? İkilemindeki etik anlayışından insan sağlığı olumsuz şekilde etkilenebilmektedir.

\section{GIDADA PAZARLAMA STRATEJİSI OLARAK SAĞLIKLI ALGILANMA ÖRNEKLERİ}

Gıda sektörü tarafindan sağlıklı algılanma etkisinin bir pazarlama stratejisi olarak kullanılması 1990'ların sonlannda "kolesterolsüz" ifadesinin bazı gidaların etiketlerinde yer almasıyla başlamışır (Fernan, et.al, 2018).

Piyasadaki rekabet ortamında, tüketici eğilim ve davranışlarını yönlendirerek talep yaratmak ve satışları artırmak için, görsel, yazılı ve sosyal medyada yeni bir görsel ve yazılı içerik kullanımı söz konusudur.

Satış amaçlı yaratılan bu yeni içerik üretimi, sağlıklı algilanma (health halo) etkisi üzerinden tüketici satın alma davranışlarının manipüle edilmesine yol açmaktadır.

\section{Gıda etiketlerindeki etik bilgilerin "sağlıklı alg1lanma etkisi"}

Üretici firmanın etikette sosyal sorumlulukları dikkate aldığını belirten etik ifadeler kullanması, çoğunlukla tüketicileri olumlu şekilde etkilemektedir.

Örneğin firmanın çevreye duyarlılık, çalışanların sosyal güvenliğinin sağlaması, kadın işgücüne öncelik, çocuk işgücü kullanılmaması konularının ilke edindiği adil ticaret (fair trade) ifadesinin etiketlerde kullanması tüketicinin o ürüne olan tercihini olumlu olarak etkilemektedir.

Bu konuda ABD'de yapılan bir çalışmada, çikolata etiketinde adil ticaret ilkelerine uygunluk (fair trade) ifadesinin yer almasının tüketici talebine olan etkisi araştırlmıştır.

Araştırmaya katılan farklı yaş, cinsiyet, eğitim ve siyasi görüşte 192 tüketici, etiketinde fair trade ifadesi bulunan çikolatayı daha az kalori içerdiğini düşünerek tercih etmiştir. Tüketici tercih yaparken, fair trade ifadesinin ürünün başka özelliklerini de iyileştirdiğini düşünmüsstür (Chandon, et.al.2007; Benson, et.al. 2018).
Gıda etiketlerindeki light, zero, diyet ifadeli içeceklerin "sağlıklı algılanma etkisi"

Tüketici özellikle şeker yerine yapay tatlandırnc1 kullanılan içeceklerin (diyet, light, zero) daha sağlıklı olduğu gibi bir yanılgıya sahiptir.

Ancak araştırmalar, diyet içecek seçeneklerinin kilo alımına neden olduğu göstermişlerdir. Fazla miktarda aspartam içeren bu içeceklerin, insülin salgisin arţşa neden olarak kan şekerini düşürüp, açlık hissi oluşturduğunu göstermektedir (Mooradian, et.al., 2017; Sylvetsky, et.al., 2018).

Gıda etiketlerindeki doğal organik katkısız ifadelerinin "sağlıklı algılanma etkisi"

Araştırmalar bir gıdanın bir yönüyle sağlıklı olarak gösterilmesinin, tüketicilerin genellikle bu giday1 tamamen sağlıklı olarak kategorize ettiklerini ve kalori içeriğini küçümseyerek fazla miktarda tükettiklerini göstermektedir.

Örneğin trans yağ içeren patates cipsi etiketinde "organik patatesten yapılmışıtır" ifadesinin olması o marka cipsin yağ ve tuz içeriğini ihmal edilmesine neden olmaktadir. Hamburgerin "anne hamburgeri" etiketiyle sunulması da tüketicide sahte bir sağlıklı olma alg1sı oluşturmakta, tüketilen gıda miktarını artırmaktadır (Chandon, et.al. 2007; Sundar, et.al. 2015).

Benzer şekilde etiketinde GDO içermeyen ifadesi taşıyan bir ürün, trans yağ ve fazla miktarda nişasta bazlı fruktoz içeren bir gida olabilir. Kişiler bu gıdaları daha sağlıklı olduğunu düşünerek fazla miktarda tüketebilir.

\section{Gıda etiketlerindeki "glutensiz" ifadesinin} "sağlıklı algılanma etkisi"

Çölyak hastalığının toplumda görülme sıklığ $\% 1$ civarında olmasına rağmen ABD'de pek çok kişi; "çölyak hastası" olmamasına rağmen, daha sağlıklı olduğunu düşünerek glutensiz gıdalanı tercih etmektedir ( L. G. H. 2016).

Çölyak dışı gluten hassasiyeti/duyarlılı̆̆ (ÇDGH) ise özellikle son on yılda adı sıkça duyulan bir durumdur. ÇDGH'nin toplumda yaklaşık \%6 oranında görüldüğü kabul edilmektedir. Bununla beraber ÇDGH tanısı için, Çölyak hastalığındaki gibi kesin tanı kriterlerinin olmaması ve çoğu kez 
tıbbi bir değerlendirme yapılmadan kişilerin kendi kendilerine bu taniyı koymalarından dolay1, hastalığın gerçek görülme sıklığı hakkında güvenilir bir veri mevcut değildir. Hastalığın görülme sıklığ1, çoğu kez anket gözlemlerine dayanan heterojen grupları içerdiğinden \%0.63-6 gibi geniş bir aralıkta bildirilmektedir. (Venter, et.al., 2016; Bektaş, et.al., 2018).

Bazı araştırmacılara göre, çölyak hastalığından biraz daha yaygin görülen ÇDGH, toplumun \% 10-20'sini etkileyen irritabl bağırsak sendromunun (IBS) bir alt grubunu olduğu düşünülmektedir. ÇDGH ile ilgili şikayetler IBS ile benzerlik göstermektedir. Bununla birlikte, her iki durumda çölyak hastalığı kadar ciddi değildir (Bektaş,et.al., 2018).

Buna karşın Tüketici Anketleri Ulusal Araştırma Merkezi tarafindan yapılan anket sonuçlarına göre, Amerikalıların \% 63'ü glutensiz bir diyetin zihinsel veya fiziksel sağlıklarına iyi geleceğine inanmaktadır. 2016'da 15.5 milyar dolarlık glutensiz diyet pazarının önümüzdeki yıllarda daha da büyüyeceği öngörülmektedir (Niland,et.al.,2018).

Glutensiz ürünlerin büyük kısmı, işlenmiş ürünlerdir. Bunlar doymuş yağ ve tuz miktarı fazla, kalorisi yüksek aynı zaman pahalı ürünlerdir. Hâlbuki buğday gibi tahıl grubu gidalar, hem ekonomik hem de kolay ulaşılabilir olmaları nedeniyle beslenmede önem taşırlar. Tahillar dünyadaki en sağlıklı diyetlerden biri olarak kabul edilen Akdeniz diyetinin ana bileşenini oluştururlar. O nedenle doktor tanısı ve tavsiyesi olmadan, sağlıklı olma açısından glutensiz diyet uygulamalarının önerilmesi doğru değildir (Bektaş, et.al. 2018; Gül, et.al., 2018; Lee, et.al., 2019; Devries, et.al., 2020).

\section{Fermente ürünlerin sağlıklı algılanma etkisi}

Dünyada 42 milyar dolarlık bir probiyotik pazar1 vardır (Holban, et.al., 2018). Dünya Sağlık Örgütü (WHO) probiyotikleri, yeterli miktarda alındıklarında insan sağlığı üzerinde faydalı etkiler gösteren canlı mikroorganizmalar (bakteri, maya) olarak tanımlamaktadır (Markowiak, et.al.,2017).
Ancak içinde canlı bakteri içeren her fermente beslenme ürünü "probiyotik gida" olarak kabul edilmez (Rezac, et.al., 2018).

Türk Gıda Kodeksine göre probiyotik gıda; içerisinde raf ömrünün sonuna kadar yeterli miktarda canlı probiyotik mikroorganizma (1 gramında ya da mililitresinde $10^{6} \mathrm{KOB}$ bakteri) bulunduran ve bunu muhafaza eden üründür (Anonim, 2006).

Yoğurt, kefir, kımız, turşu, boza, kombu çayı vb gıda ancak yukarıda bahsi geçen miktarda probiyotik özellikte bakteri taşıyorsa; probiyotik ürün olarak kabul edilir (Talati, et.al., 2016; WGO, 2017).

Bir gıdanın probiyotik özelliğini, yüksek 1sıya maruz kalması, raf ömrünü tamamlamıs olması, ve g1daya baz1 kimyasalların ilave edilmesi bozar (Van den Nieuwboer, et.al., 2016; Flach, et.al., 2018; Fenster, et.al., 2019).

Kopenhag Üniversitesi'nde herhangi bir sponsor desteği olmadan probiyotik takviyeli bisküvi, süt bazlı içecekler ve kapsüllerin incelendiği yedi farkl1 randomize-plasebo kontrollü çalışma masaya yatırrlmıştır. Araştırmada bu ürünleri tüketen kişilerin dışk1 örneklerinde probiyotik bakteri çeşitliliğinin değişip değişmediği incelenmiş, bu çalışmalardan sadece birinde istatistiksel olarak anlamlı bir değişiklik bulunmuştur. Ancak bunun da klinik fayda sağladığına dair herhangi bir kanıt bulunmamaktadır (Kristensen, et.al., 2016).

\section{Sporcu içecekleri ve protein barlarının sağlıklı algilanma etkisi}

The California Center for Public Health Advocacy(CDC)raporuna göre, milyonlarca dolarlık sporcu içecekleri endüstrisi insanlan bu içeceklerin faydası konusunda ikna etmek için "Health Halo" etkisi oluşturmaya çalışmaktadır. ABD'de içecek endüstrisi, okullarda gençlerin tercihlerini etkileyerek tüketimi artırmak için yılda 71 milyon dolardan fazla harcama yapmaktadır. Dünyadaki en büyük otomobil yarışı Formula-1'in destekleyicisi ünlü bir enerji içeceği markasıdır. 
CDC araştırmacılarının 2011'de yaptıkları bir ankete göre 12-17 yaş arası gençlerin yüzde 20'si enerji içeceklerinin gençler için güvenli içecekler olduğuna inanmaktadır. Raporda sporcu içecekleri konusunda özellikle ebeveynlerin bilinçlendirilmesi ve çocukların bu takviyelerden uzak tutulması gerektiği konusunda vurgu yapilmıstır. Çünkü bu tür içecekler özellikle çocuklar için zararlı olabilecek çeşitli maddeler içermeleri yanında, fazla miktarda şeker taşıdıkları için obezite ve diyabet riskini de arttırmaktadır (Crawford, et.al., 2014).

Benzer şekilde doğal birçok protein kaynağı gida varken, bu gün ABD'de her beş kişiden biri sağlıklı olduğuna inandığı için protein barlarını diyetlerine alarak, günlük protein ihtiyaçlarını tamamladıklarını düşünmektedir (Holban, et.al., 2018).

\section{Amerikan obezite paradoksu}

1991-2001 yılları arasında genç yaştaki Amerikalılarda obezite \%23'den \%31'e çıkmıştur. Aynı sürede düşük kalorili yiyecek ve içecek tüketimi ise $\% 48$ den \% 60'a çıkmıştır. Bu süre içinde ulusal tüketici anketlerine göre Amerika'da "sağlıklı diyet" (healthy diet) tüketim oranı yılda \% 6 oranında artmışır.

Ancak düşük kalorili içecek ya da yiyecek tüketimi beklendiği gibi obeziteyi azaltmamış tersine artırmıştır. Buna "Amerikan obezite paradoksu" denilmektedir. Bir başka anlatımla Amerikalılar etiketinde "light" ya da "diyet" yazan bir ürünü aşırı miktarda tüketerek fark etmeden fazla kalori almakta, dolayısıyla kilo vermek isterken kilo alabilmektedirler. Gıda tercihlerinin daha çok damak zevkine göre yapıldığı Belçika ve Fransa'da ise, obezite Amerika'ya göre daha düşük oranda görülmektedir. (Chandon, et.al. 2007).

Diğer taraftan araştırmalar bir gidanın bir yönüyle sağlıklı olarak gösterilmesi durumunda, tüketicilerin genellikle bu gıdayı tamamen sağlıklı olarak kategorize ettiklerini ve kalori içeriğini küçümseyerek fazla miktarda tükettiklerini göstermektedir.
Journal of Consumer Research yayınlanan bir araştırmada, A zincir restoranlarının, B zincir restoranlarına göre daha sağlıklı olduğu yönündeki alg1, Illinois Üniversitesindeki 320 ögrenci ve çalışanın tercihleri üzerinden analiz edilmiştir. Araştırma, deneklerin aynı miktarda kalori içermesine rağmen, A zincir restoranlarının daha az kalori içerdiğine inanıp, menüye tatlı veya içecek ilave ettiklerini göstermiştir. (Chandon, et.al., 2007).

\section{TÜRKIIYE'DE "SAĞLIKLI ALGILANMA ETKİII" KONUSUNDA YASAL DÜZENLEMELER VE ÖRNEKLER}

Sağlıklı algılanma (health halo) etkisinin gida sanayisi tarafindan bir pazarlama stratejisi olarak kullanilması, 90'lı yilların sonlanında "kolesterolsüz" ifadesinin baz1 gidaların etiketlerinde yer almasıyla başlamışur (Fernan, et.al., 2018). "Health halo" Türkçe kelime olarak tam bir karşllı̆ı olmasa da "sağlıklı algılanma etkisi" olarak ifade edilebilir.

Sağlıklı algılanma etkisi pazarlama stratejisi olarak ülkemizde de uygulanmaktadır. Konuyla ilgili mevzuat: 29/12/2011 tarih ve 28157 üçüncü mükerrer sayılı Resmî Gazetede yayınlanan "Türk Gıda Kodeksi Etiketleme Yönetmeliği", 26 Ocak 2017 tarih ve 29960 mükerrer sayll Resmi Gazetede yayınlanan "Türk Gıda Kodeksi Gıda Etiketleme ve Tüketicileri Bilgilendirme Yönetmeliği" ve kılavuzudur.

Mevzuat ve uygulama kilavuzunda konuyla ilgili bilgi ve açıklamalar mevcuttur. Gida etiketlerindeki bilgilerin gidanın niteliklerini yansıtmas1, etiketlerdeki gösterimler ve resimlerin, gıdanın çeşidi, bileşimi, kalitesi veya menşei açısından tüketiciyi yanıltmaması gerektiği belirtilmektedir.

Etiketlerde yer alan doğal, katkısız, negatif/pozitif beyanlar, var-yok tanımları, \% 100 ifadelerinin nasıl kullanılacağı açıklanmıştır. Gıda etiketlerde "saf, gerçek ve hakiki" ifadelerinin kullanımı yasaktur. "Geleneksel" ifadesi ise, Türk Patent Enstitüsü tarafindan tescil edilmiş ürünler için kullanılabilir. "Ev yapımı, anne eli değmiş" gibi 
ifadeler, endüstriyel ölçekte üretilen gıdalar için kullanilamaz.

Ancak, ev yapımı tadında, anne eli değmiş gibi, geleneksel tat vb. ifadeler tüketici tercihine bırakıldığından kullanılabilir. Süper, bol, ekstra, daha fazla ifadelerinin kullanım şekilleri de aynı kılavuzda belirtilmiştir. "Anne hamburgeri" ifadesi yasal açıdan kullanılması uygun olmakla birlikte gerçekten sağlıklı mıdır? Meyve suyu konsantrelerinin "Vitamin" ya da "Antioksidan" ismi altında satılması doğru mu? Tüm bu soruların cevapları tartışmaya açıktır.

\section{SONUÇ VE DEĞERLENDİRME}

Gıda etiket bilgilerinde standartlaşmaya gidilmesi, konuyla ilgili mevzuatlar üzerinden etiket bilgilerinin kontrol ve denetlemelerinin yapilmas1 önemlidir. Bu konuda, "Sağlıklı algılanma etkisi" yaratan zihinsel kısa yolları devre dışı bırakmak için tüm gıdalarda düz/sade paketleme (plain package) uygulanması söz konusu olabilir.

Tüketicilerin günlük diyet seçimlerinde "Akdeniz diyeti" beslenme tarzı, doğal, işlenmemiş gidalara ve yerel ürünlere öncelik vermesi önem taşır. Bu konuda üreticilerin desteklenmesi tüketicilerin bilinçlendirilmesi gıda güvenliği ve sağlık politikalarının öncelikleri arasında yer almalıdır.

\section{ÇIKAR ÇATIŞMASI}

$\mathrm{Bu}$ makalede yazarların, diğer kişilerin ve kurumların arasında bir çıkar çatısması yoktur.

\section{YAZAR KATKILARI}

$\mathrm{AB}$ makale konusunu araştırdı ve tasarladı. AB, VB ve MU makaleyi yazdi. Tüm yazarlar makalenin son halini okudu ve onayladi.

\section{KAYNAKLAR}

Anonim, (2006). Türk Gıda Kodeksi Gıda Maddelerinin Genel Etiketleme Ve Beslenme Yönünden Etiketleme Kuralları Tebliğinde Değişiklik Yapılması Hakkında Tebliğ. Tebliğ No (2006/34). Say1 26221.

Ares, G., Giménez, A., Gámbaro, A. (2009). Consumer perceived healthiness and willingness to try functional milk desserts. Influence of ingredient, ingredient name and health claim. Food Qual and Preference, 20(1), 50-56.

Barreiro-Hurle, J., Gracia, A., De.Magistris, T. (2010). The effects of multiple health and nutrition labels on consumer food choices. $J$ Agricult Econ, 61(2), 426-443.

Bektaş, A., Özel, M. (2018). Gluten: Dost mu, Düşman mı? Güncel Gastroenteroloji 22/2. ISSN 1301-2487.

http://guncel.tgv.org.tr/journal/74/pdf/100584 .pdf

Benson, T., Lavelle, F., Bucher, T., McCloat, A., Mooney, E., Egan, B., Dean, M. (2018). The impact of nutrition and health claims on consumer perceptions and portion size selection: results from a nationally representative survey. Nutr, 10(5), 656.

Carpenter, K. J. (2003). A short history of nutritional science: Part 1 (1785-1885). J Nutr, 133(3), 638-645.

Castro-Quezada, I., Román-Viñas, B., SerraMajem, L. (2014). The Mediterranean diet and nutritional adequacy: A review. Nutrients, 6(1), 231-248.

Chandon, P., Wansink, B. (2007). The biasing health halos of fast-food restaurant health claims: lower calorie estimates and higher side-dish consumption intentions. J Consumer Res, 34(3), 301-314.

Crawford, P., Atkins, V., Goldstein, H., (2014). Hiding Under a Health Halo: Examining the Data Behind Health Claims on Sugary Beverages. https://phadvocates.org/wpcontent/uploads/2019/11/Health-Halo-PolicyBrief.pdf

Devries, S., Van Horn, L., Willett, W. (2020). The Mediterranean Diet. Med Roundtable Gen Med Ed.; 1(1): 42-49.

Dixon, H., Scully, M., Wakefield, M., Kelly, B., Chapman, K., Donovan, R. (2011). Parent's responses to nutrient claims and sports celebrity endorsements on energy-dense and nutrient-poor foods: an experimental study. Public Health Nutr, 14(6), 1071-1079. 
FDA, (2018). Authorized Health Claims That Meet the Significant Scientific Agreement (SSA) Standard. https://www.fda.gov/food/labelingnutrition/uc m2006876.htm, 21 CFR 101.

Fenster, K., Freeburg, B., Hollard, C., Wong, C., Rønhave Laursen, R., Ouwehand, A. C. (2019). The production and delivery of probiotics: $\mathrm{A}$ review of a practical approach. Microorg, 7(3), 83.

Fernan, C., Schuldt, J. P., Niederdeppe, J. (2018). Health halo effects from product titles and nutrient content claims in the context of "protein" bars. Health Commun, 33(12), 1425-1433.

Flach, J., van der Waal, M. B., van den Nieuwboer, M., Claassen, E., Larsen, O. F. (2018). The underexposed role of food matrices in probiotic products: Reviewing the relationship between carrier matrices and product parameters. Crit Rev Food Sci Nutr, 58(15), 2570-2584.

Guasch-Ferré, M., Dashti, H. S., Merino, J. (2018). Nutritional genomics and direct-toconsumer genetic testing: an overview. Adv Nutr, 9(2), 128-135.

Gül, H., Hayit, F., Acun, S., Tekeli, S. G. (2018). Improvement of quality characteristics of glutenfree cookies with the addition of xanthan gum. In "Agriculture for Life, Life for Agriculture" Conf Proc (Vol. 1, No. 1, pp. 529-535). Sciendo.

Hasler, C. M. (1998). Functional foods: their role in disease prevention and health promotion. Food Technology-Champaign Then Chicago-, 52, 63147.

Holban, M. A., Grumezescu, M. A., (Ed.). (2018). Diet, Microbiome and health. Handbook of Food Bioengineering Volume 11. Academic press is an imprint of Elsivier. United Kingdom.

Hwang, J., Lee, K., Lin, T. N. (2016). Ingredient labeling and health claims influencing consumer perceptions, purchase intentions, and willingness to pay. J Food service Business Res, 19(4), 352-367.

Ikonen, I., Sotgiu, F., Aydinli, A., Verlegh, P. W. (2019). Consumer effects of front-of-package nutrition labeling: an interdisciplinary metaanalysis. J Acad Marketing Sci, 1-24.
Kapsak, W. R., Schmidt, D., Childs, N. M., Meunier, J., White, C. (2008). Consumer perceptions of graded, graphic and text label presentations for qualified health claims. Crit Rev Food Sci Nutr, 48(3), 248-256.

Kristensen, N. B., Bryrup, T., Allin, K. H., Nielsen, T., Hansen, T. H., Pedersen, O. (2016). Alterations in fecal microbiota composition by probiotic supplementation in healthy adults: a systematic review of randomized controlled trials. Genome Med, 8(1), 52.

Lee, A. R., Wolf, R. L., Lebwohl, B., Ciaccio, E. J., Green, P. H. (2019). Persistent economic burden of the gluten free diet. Nutr, 11(2), 399.

Lee, W. J. (2019). Vitamin C in Human Health and Disease: Effects, Mechanisms of Action, and New Guidance on Intake. Springer.

Markowiak, P., Śliżewska, K. (2017). Effects of probiotics, prebiotics, and synbiotics on human health. Nutr, 9(9), 1021.

Maubach, N., Hoek, J., Mather, D. (2014). Interpretive front-of-pack nutrition labels. Comparing competing recommendations. Appetite, 82, 67-77.

Méjean, C., Macouillard, P., Péneau, S., Hercberg, S., Castetbon, K. (2013). Perception of front-ofpack labels according to social characteristics, nutritional knowledge and food purchasing habits. Public Health Nutr, 16(3), 392-402.

Mentella, M. C., Scaldaferri, F., Ricci, C., Gasbarrini, A., Miggiano, G. A. D. (2019). Cancer and Mediterranean Diet: A Review. Nutr, 11(9), 2059.

Mooradian, A. D., Smith, M., Tokuda, M. (2017). The role of artificial and natural sweeteners in reducing the consumption of table sugar: A narrative review. Clin Nutr Espen, 18, 1-8.

Mozaffarian, D. (2016). Dietary and policy priorities for cardiovascular disease, diabetes, and obesity: A comprehensive review. Circulation, 133(2), 187-225.

Niland, B., Cash, B. D. (2018). Health benefits and adverse effects of a gluten-free diet in non- 
celiac disease patients. Gastroenterol Hepatol, 14(2), 82.

Orquin, J. L., Scholderer, J. (2015). Consumer judgments of explicit and implied health claims on foods: Misguided but not misled. Food Policy, 51, 144-157.

Percival, M. (1997). The importance of optimal nutrition. Clin Nutr Insights, 5, 1-6.

Phelan, J. C., Link, B. G., Feldman, N. M. (2013). The genomic revolution and beliefs about essential racial differences: A backdoor to eugenics? Am sociological review, 78(2), 167-191.

Rezac, S., Kok, C. R., Heermann, M., Hutkins, R. (2018). Fermented foods as a dietary source of live organisms. Front microbiol, 9, 1785.

Roberto, C. A., Khandpur, N. (2014). Improving the design of nutrition labels to promote healthier food choices and reasonable portion sizes. Int $J$ Obes, 38(1), S25-S33.

Shamim, N., Gupta, A., Paul, V., Vida, E. (2017). Nutritional genomics: A review. The Pharma Innov, 6(4, Part A), 17.

Shao, A., Drewnowski, A., Willcox, D. C., Krämer, L., Lausted, C., Eggersdorfer, M., Griffiths, J. C. (2017). Optimal nutrition and the ever-changing dietary landscape: a conference report. EurJ Nutr, 56(1), 1-21.

Siegrist, M., Leins-Hess, R., Keller, C. (2015). Which front-of-pack nutrition label is the most efficient one? The results of an eye-tracker study. Food Qual Pref, 39, 183-190.

Sundar, A., Kardes, F. R. (2015). The role of perceived variability and the health halo effect in nutritional inference and consumption. Psychol Marketing, 32(5), 512-521.

Sylvetsky, A. C., Rother, K. I. (2018). Nonnutritive sweeteners in weight management and chronic disease: A review. Obesity, 26(4), 635640.

Talati, Z., Pettigrew, S., Dixon, H., Neal, B., Ball, K., Hughes, C. (2016). Do health claims and front-of-pack labels lead to a positivity bias in unhealthy foods? Nutr, 8(12), 787.
The, L. G. H. (2016). Gluten: going against the grain? The Lancet Gastroenterol Hepatol, 1(2), 85.

Trujillo, E., Davis, C., Milner, J. (2006). Nutrigenomics, proteomics, metabolomics, and the practice of dietetics. J Am Diet Assoc, 106(3), 403-413.

Van den Nieuwboer, M., van Hemert, S., Claassen, E., de Vos, W. M. (2016). Lactobacillus plantarum WCFS 1 and its host interaction: a dozen years after the genome. Microb biotechnol, 9(4), 452-465.

Van Herpen, E., Hieke, S., Van Trijp, H. C. (2014). Inferring product healthfulness from nutrition labelling. The influence of reference points. Appetite, 72, 138-149.

Van Ommen, G. J. (2002). The Human Genome Project and the future of diagnostics, treatment and prevention. J Inherit Metab Dis, 25(3), 183-188.

Venter, C., Maslin, K., Arshad, S. H., Patil, V., Grundy, J., Glasbey, G., Dean, T. (2016). Very low prevalence of $\mathrm{IgE}$ mediated wheat allergy and high levels of cross-sensitisation between grass and wheat in a UK birth cohort. Clin Translational Allergy, 6(1), 22.

Wansink, B. (2003). How do front and back package labels influence beliefs about health claims?. J Consumer Affairs, 37(2), 305-316.

Wansink, B., Chandon, P. (2006). Can "low-fat" nutrition labels lead to obesity? J Marketing Res, 43(4), 605-617.

WGO Review Team (2017). Probiotics and prebiotics. World Gastroenterology Organisation Global Guidelines.

Wilkins, S., Butt, M. M., Shams, F., Pérez Ruiz, A. (2019). The acceptance of halal food in nonMuslim countries: Effects of religious identity, national identification, consumer ethnocentrism and consumer cosmopolitanism. Vol. 10 No. 4, pp. $1308-1331$

Wilkins, S., Butt, M. M., Shams, F., Pérez, A. (2019). Product standardisation in the food service industry: post-purchase attitudes and repurchase intentions of non-Muslims after 
consuming halal food. J Strategic Marketing, 27(3), 210-226.

Wong, C. L., Mendoza, J., Henson, S. J., Qi, Y., Lou, W., L'abbé, M. R. (2014). Consumer attitudes and understanding of cholesterollowering claims on food: randomize mockpackage experiments with plant sterol and oat fibre claims. Eur J Clin Nutr, 68(8), 946-952.
World Health Organization. (2010) Indicators for assessing infant and young child feeding practices: Part III Country Profiles. WHO, Geneva. 